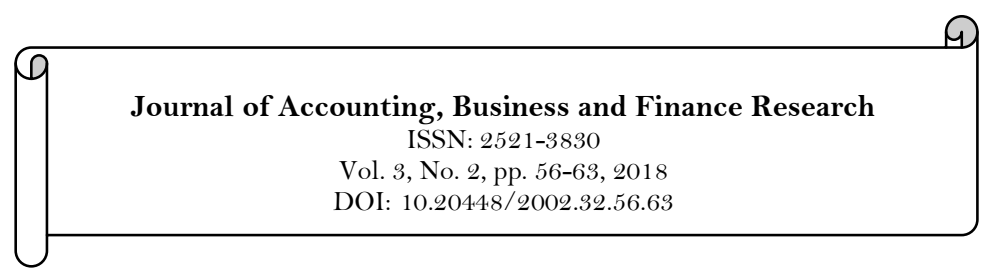

\title{
The Impact of Macroprudential Supervision on the Capital Operation of Commercial Banks
}

\author{
Chen $\mathrm{Zhu}^{1 \mathrm{~s}}$ \\ Liping Chen ${ }^{2}$
}

${ }^{1}$ Finance School of Nanjing University of Finance and Economics, China, Business School of Florida International University, U.S. Email: cahu(afiu.edu

${ }^{2}$ School of Foreign Languages and Cultures, Nanjing Normal University, China.

Abstract
\begin{tabular}{l|l} 
Based on the 8320 observations in 40 quarters of 16 listed banks, this & Keywords: \\
paper empirically analyses the macro-prudential supervision's impact & $\begin{array}{l}\text { Macro-prudential supervision } \\
\text { Commercial bank }\end{array}$ \\
on commercial bank's capital operation through the dynamic & Capital operation \\
unbalanced panel system GMM model. The results show that & Economic cycle. \\
macro-prudential supervision has exerted active supervision on & \\
China's commercial banks, guiding China's commercial banks to & JEL Classification: G21; G23; \\
establish a capital restraint mechanism and improving the bank's & G28. \\
internal capital supplement mechanism. The response of commercial & Licensed: \\
banks to capital supervision is positive. The regulatory rating results & This work is licensed under a \\
influence the active adjustment of the bank's follow-on capital ratio. & Creative Commons Attribution \\
Commercial banks basically meet the requirements for prudent & 4.0 License. \\
management of countercyclical capital. Based on the analysis of the & Publisher: \\
data in the article, this paper suggests that the regulatory authorities & Scientific Publishing Institute \\
further strengthen the bank's capital supervision and make the bank's & \\
macro-prudential supervision appear more counter-cyclical. At the & \\
same time, we must appropriately improve the banking ownership \\
structure, increase the sources of external funds for commercial
\end{tabular}
banks, and enhance the transparency of the financial system so that
uninsured loan holders can play a significant role in binding banks.

\section{Introduction}

Banks play a key role in allocating effective economic resources. However, banks themselves are vulnerable and opaque. If supervision is not in place, it may bring instability to the entire financial system and bring high costs to the society. Originating in 2008, the U.S. global financial crisis has exposed the lack of financial supervision. For this reason, international organizations such as the Financial Stability Board, the Basel Committee, and the International Monetary Fund have actively pursued a macro-prudential model in an attempt to curb the pro-cyclical behaviour of various financial institutions. In accordance with the requirements of Basel III, banks must possess net-value collateral assets that are proportionate to risky assets, minimize bank speculation, and protect banks from financial shocks. With the implementation of Basel III, the People's Bank of China began implementing the "Administrative Measures for the Capital Management of Commercial Banks (Trial)” in 2013, which puts forward requirements for the capital adequacy of systemically important banks and non-systemically important banks. The China Banking Regulatory Commission jointly promotes the new capital agreement.

With the advancement of macroprudential policies, more and more researchers have begun to pay attention to the capital operations of financial institutions, especially capital buffers. Judging from the existing research content, the study covers many aspects of capital operations. For example, existing evidence shows that the capital adequacy ratio of banks is far higher than the required requirements. Therefore, many researchers are exploring the banks' main motivation to hold capital buffers. Milne and Whalley (2001) and Milnes (2004) established a dynamic model of bank capital decisions. They found that when accepting capital controls, bankers will balance costs and profits from various aspects. For example, when they violate the minimum regulatory requirements, they will suffer from punishment, the cost of holding surplus capital, and 
the cost and time limit of adjusting capital level, etc. These models have important implications for the study of capital control.

Another series of research on capital operations is related to the cyclical nature of the economy. Ayuso, Pérez, and Saurina (2004) studied the impact of the business cycle on bank behaviour and provided evidence that capital operations may be pro-cyclical. That is, banks tightened their balance sheets during economic recession and banks expanded balance sheets during economic growth. However, some researchers have come to the opposite conclusion. Jokipii and Milne (2008) found that the banks of countries that have just joined the European Union showed counter-cyclical behaviour. Francis and Osborne (2009) reached a similar conclusion when they studied the capital behaviour of British banks. Estrella (2004) summarized periodic oscillations in a dynamic model. The results of this study indicate that the most appropriate capital level is negatively related to the value-in-risk capital limit throughout the entire cycle. The model also gives useful insights on financial stability.

There are also researchers who are exploring external factors that affect the level of capital. Blum (2002), Francis and Osborne (2009) find that wholesale funding markets and subprime mortgage debt may lead banks to take greater risks. Therefore, they propose to limit subprime mortgage debt. Nier and Baumann (2006) found that the market played a constraint role. In addition, Fonseca and González (2010) found that differences in country-to-country regulatory systems, accounting disclosure systems, and deposit insurance systems all affect bank capital retention.

Domestic researchers also conducted a lot of research, mainly focusing on the cyclical characteristics of capital operations, factors that affect capital retention, and capital operating mechanisms.

Overall, existing research covers the essential attributes of capital operations, the relationship between capital operations and economic cycles, and the factors that affect the financial institutions' holding of net capital. However, there is not much research on the impact of macro-prudential supervision on the capital operation of commercial banks. In view of this, this paper will use the dynamic unbalanced panel system GMM model and the data of state-owned large-scale banks, joint-stock listed banks, and some city commercial banks from 2006 to 2016 to analyse the impact of macro-prudential supervision on the capital operation of commercial banks.

The rest of the paper consists of research design, data processing, results analysis, and the conclusion and recommendations.

\section{Research Design}

\subsection{Establishing a Dynamic Model of Capital Buffering}

Based on the capital buffer adjustment model constructed by Francis and Osborne (2009) and by controlling the bank's output capacity, market evaluation, account items, and structural characteristics, such as scale, business management, market constraints, regulatory oversight, economic environment, etc., this study explores the relationship between risk and target capital ratio. By using the difference between the bank's capital ratio and the above variables, we explain the various banks' capital operations.

Specifically, based on a dynamic empirical model, we measure the relationship between bank's net capital retention and banking business elements by calculating the costs of capital regulation and capital control. In the following equations, the capital adjustment $\Delta \mathrm{BUF}_{\mathrm{i}, \mathrm{t}}$ is dynamically changing. Bank i only partially reaches the optimal buffer between $\mathrm{t}-1$ and $\mathrm{t}, \Delta \mathrm{BUF}_{\mathrm{i}, \mathrm{t}}^{*}$. As the adjustment cost decreases, the proportion and speed $\theta$ of the cost adjustment will increase. When the adjustment cost is 0 , the capital is fully adjusted $(\theta=1)$, and the observed buffer $\mathbf{B U F}_{i, \mathrm{t}}$ is just equal to the most appropriate plus an exogenous error factor, $\mathbf{u}_{\mathrm{i}, \mathrm{t}}$ :

$$
\begin{aligned}
\Delta \mathrm{BUF}_{\mathrm{i}, \mathrm{t}}=\theta\left(\Delta \mathrm{BUF}_{\mathrm{i}, \mathrm{t}}^{*}-\mathrm{BUF}_{\mathrm{i}, \mathrm{t}-1}\right)+\mathrm{u}_{\mathrm{i}, \mathrm{t}} \text { 或BUF } & \mathrm{BUF}_{\mathrm{i}, \mathrm{t}} \\
& =(1-\theta) \mathrm{BUF}_{\mathrm{i}, \mathrm{t}-1}+\theta \mathrm{BUF}_{\mathrm{i}, \mathrm{t}}^{*}+\mathrm{u}_{\mathrm{i}, \mathrm{t}}
\end{aligned}
$$

Of course, the capital optimization buffer also includes other factors. In light of previous research, this study believes that capital optimization buffering can be seen as a function of four fundamental factors that influence bank decisions, see Equation 2. First, the impact of the banking business model (MNG); second, the regulatory pressure (SUP); third, the market pressure (MKT); and finally, the economic environment (CYCLE).

$$
\mathrm{BUF}_{\mathrm{i}, \mathrm{t}}^{*}=f(\mathrm{MNG}, \mathrm{SUP}, \mathrm{MKT}, \mathrm{CYCLE}) \quad(2)
$$

The first three influencing factors correspond to the three regulations in Basel II. The fourth factor is the basis for the macro-prudential management requirements in the New Basel Agreement. Each influencing factor has specific indicators. See the following equation:

$$
\begin{aligned}
& \text { BUF }_{\mathrm{i}, \mathrm{t}}=(1-\theta) \mathrm{BUF}_{\mathrm{i}, \mathrm{t}-1}+\alpha_{1} \mathrm{ROE}_{\mathrm{i}, \mathrm{t}}+\alpha_{2} \mathrm{NPL}_{\mathrm{i}, \mathrm{t}}+\alpha_{3} \mathrm{VOL}_{\mathrm{i}, \mathrm{t}}+\alpha_{4} \operatorname{SIZE}_{\mathrm{i}, \mathrm{t}}+\alpha_{5} \mathrm{LIQUID}_{\mathrm{i}, \mathrm{t}}+ \\
& \gamma_{2} \text { PEER }_{\mathrm{i}, \mathrm{t}}+\mu_{1} \mathrm{GDPG}_{\mathrm{i}, \mathrm{t}}+\mu_{2} \mathrm{LOANG}_{\mathrm{i}, \mathrm{t}}+\text { DModel }+ \text { TimeDummies }+\mathrm{K}+\eta_{\mathrm{i}}+\varepsilon_{\mathrm{i}, \mathrm{t}}
\end{aligned}
$$




\subsection{Explanation of Explanatory Variables}

Table 1 lists the main explanatory variables and their expected values involved in this study.

Table-1. Explain variables and expectations

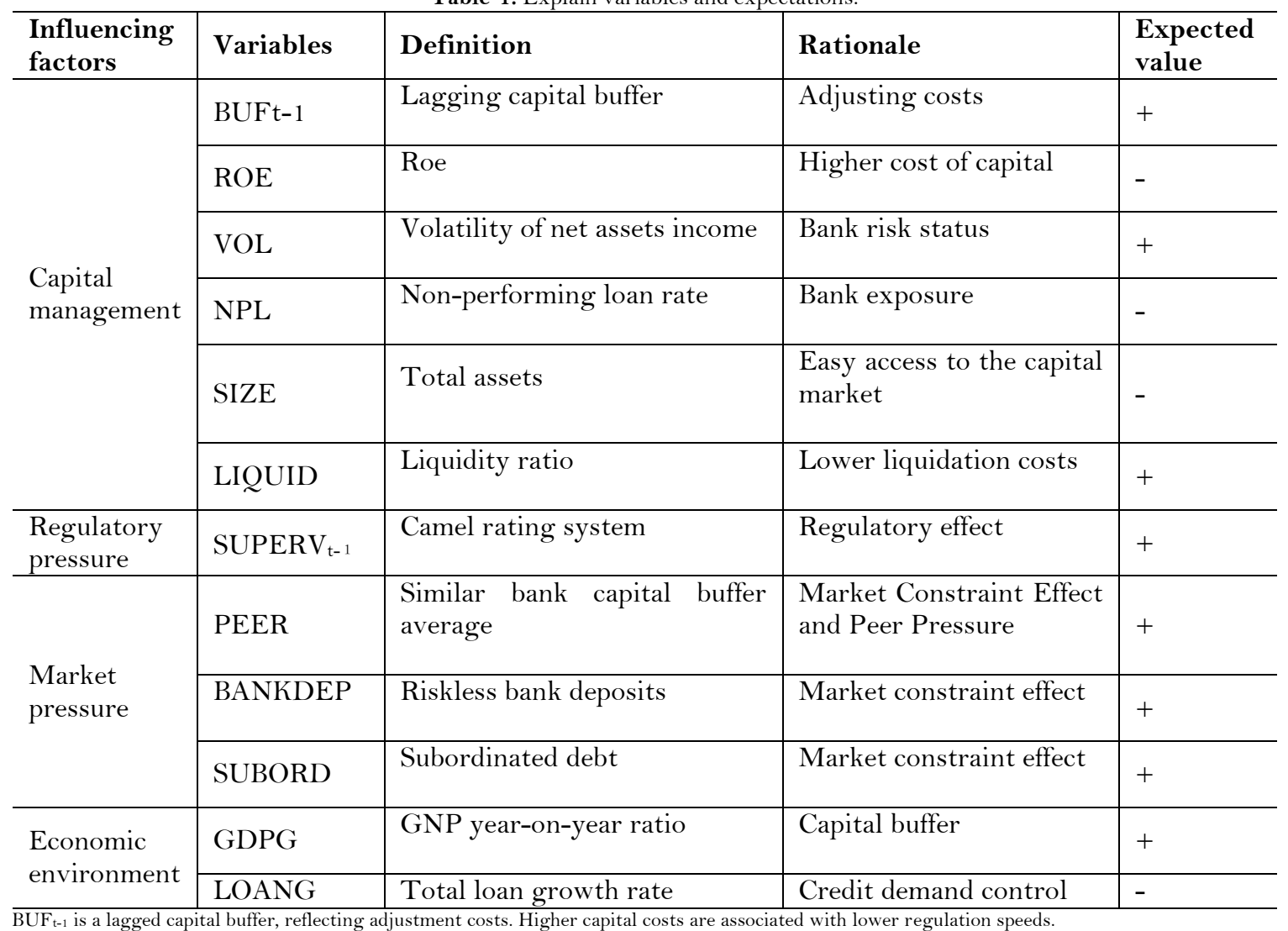

\subsection{Capital Management Includes the Following Indicators}

ROE (return on equity). From the perspective of trade-off theory, the cost of capital is high, and it is expected that the value is negative. However, from the perspective of preferential order financing theory, as an important source of capitalization, it is expected that the value is positive.

NPL is a non-performing loans and represents the exposure of the company. It is expected that the value will be negative.

SIZE means total assets. The wider the route of access to the capital market, the more diversified, the better the investment opportunity, and the less likely it is to have a capital buffer. It is expected that the value will be negative.

LIQUID is a liquid asset. The greater the liquidity, the lower the liquidation cost.

\subsection{Regulatory Pressure}

Supervision is mainly reflected in SUPERV $\mathrm{t}_{\mathrm{t}-1}$, the supervisory CAMEL ratings system, and the expected regulatory effect is positive.

\subsection{Market Pressure}

SUBORD is a subordinated debt, which reflects market constraints and has a positive expected effect.

BANKDEP is a risk-free bank deposit that reflects market constraints and expects positive results.

PEER is peer pressure and is represented by the average of capital buffers in peer groups, reflecting another variable in market constraints with positive expectations.

\subsection{Economic Environment}

GDPG is the GDP growth. If it is wise capital management, it is expected that the value is positive; if it is short-sighted capital management, it is expected that the value is negative.

LOANG is a loan growth that reflects the change in credit demand of a single bank and expects the value to be positive.

The expected values of the relevant variables are given based on the results of previous studies. For example, existing studies show that the three main factors affecting the capital buffer are adjustment costs, capital profitability, and bank's risk appetite. Like other companies, a bank with maximized profits may balance 
the cost of holding the remaining capital and the cost incurred when the operation fails. When the opportunity cost of capital is high, bankers may hold a lower capital ratio. Conversely, if bankruptcy is violated by regulatory requirements, the banker may choose a higher capital standard. In this way, as the regulatory authorities expect, banks with greater risks will have greater capital buffers. Therefore, from the trade-off point of view, the net value of mortgage assets (ROE) can be used to represent the cost of the net assets to pay the net worth, the expected value is negative.

Although from the trade-off point of view, the expected value of ROE is negative, however, when the profit becomes the main source of recapitalization, the expected value should be positive, which is consistent with the PSE theory. In fact, researchers have distinguished the reasons for the positive correlation between bank profits and capital ratios long before. Under a diversified framework, as long as marginal profits are not distributed as dividends, higher profits will lead to an increase in capital. If investors are unwilling to take risks and the market is not perfect, then the increase in capital will reduce the cost of bankruptcy and the expected rate of return of the market, which will increase the expected profit.

\section{Data Processing}

The data includes quarterly information on major state-owned banks, joint-stock listed banks and some city commercial banks from the fourth quarter of 2006 to the third quarter of 2016. There are a total of 22 listed banks in China, excluding Jiangyin Bank, Wuxi Bank, Jiangsu Bank, Hangzhou Bank, Changshu Bank, and Guiyang Bank, which were only recently listed. The final data consists of three types, 16 listed banks, 40 quarters, and 8320 observations or calculated value composition. The specific data includes description information of each bank, balance sheet, account information, and operating parameters that are regularly sent to the central bank.

The bank's capital buffer BUF is calculated as a percentage of the excess regulatory capital and risk weight assets, and its value can also be calculated by subtracting the specified minimum capital adequacy ratio from the actual capital adequacy ratio. The capital adequacy ratio of the Bank of China is far higher than the $8 \%$ required by the regulation, and the average value in the sample has reached nearly $11.95 \%$.

ROE is the percentage of the company's after-tax profit divided by net assets. The volatility of the ROE for the last four quarters based on the standard deviation measure defines the volatility VOL of net assets. The average quarterly return on net assets was $13.02 \%$, and the average return on net assets was $2.56 \%$. As a complement to the bank's risk profile, the NPL ratio is defined as the ratio of non-performing loans of financial institutions to the total loan balance. When the loan and the interest are overdue for more than 90 days, the loan is regarded as a non-performing loan.

The size of the bank SIZE is defined by the total bank assets. In the sample, 16 listed banks accounted for $70 \%$ of the total assets of the banking industry in the third quarter of 2016, and ICBC alone accounted for $53 \%$. Liquidity ratio LIQUID is the ratio of current assets to current liabilities. Most of the current assets are cash and government bonds held in combination.

The risk-free bank deposit BANKDEP is measured by the bank's cash and deposits with the central bank, plus the interbank deposits divided by the total bank deposits. Peer-to-peer capital buffer PEER is calculated based on the bank capital buffer average with similar business strategy and scale. According to the classification method adopted by the People's Bank of China, listed banks can be divided into three categories: 1) large state-owned banks; 2) joint-stock listed banks; and 3) city commercial banks. In the sample, about $31 \%$ of banks are state-owned banks, 50\% are joint-stock listed banks, and 19\% are city commercial banks.

In terms of economic environment, we have increased the GDP growth ratio of GDP in the current quarter, which can represent the domestic economic cycle. The GDPG is calculated from the ratio of the real growth rate of one quarter of GDP to the GDP of the same quarter of the previous year.

Table-2. Statistical description.

\begin{tabular}{|c|c|c|c|c|c|}
\hline Variable Name & Number of Samples & Mean & Standard Deviation & Min & Max \\
\hline BUF & 640 & 3.95 & 2.57 & -8.39 & 22.67 \\
\hline $\mathrm{ROE}$ & 640 & 13.02 & 7.60 & 2.51 & 128.55 \\
\hline VOL & 640 & 2.56 & 38.63 & -87.07 & 515.51 \\
\hline NPL & 640 & 1.56 & 2.33 & 0.33 & 23.5 \\
\hline SIZE & 640 & 0.47 & 0.54 & 0.0056 & 2.36 \\
\hline LIQUID & 639 & 43.63 & 9.29 & 25.49 & 79.76 \\
\hline SUBORD & 640 & 0.73 & 1.59 & 0.20 & 19.69 \\
\hline BANKDEP & 640 & 23.14 & 5.62 & 2.26 & 45.56 \\
\hline PEER & 640 & 3.95 & 2.05 & 0.21 & 15.93 \\
\hline SUPERV & 640 & 694.72 & 896.68 & 3.93 & 3615.26 \\
\hline LOANG & 640 & 4.62 & 4.05 & -11.61 & 35.02 \\
\hline GDPG & 640 & 9.16 & 2.39 & 6.4 & 15 \\
\hline
\end{tabular}

Source: the data is taken from WIN.D. 
A negative value indicates that the bank's business model is short-sighted, because in several banking systems, the reverse interaction between the bank's capital buffer and the economic growth variables indicates that the economic cycle may greatly affect the bank's behaviour. The growth rate of the total loan amount of a single bank is also taken into account. The growth of the individual credit portfolio in the sample is significant, with an average increase of $4.62 \%$ in each quarter.

Finally, we included a dummy variable, DModel, in the capital requirements management model to control the medium-term changes. We also included quarterly and annual dummy variables Time Dummies to obtain quarterly characteristics and annual characteristics of the sample.

Table 2 presents the basic data of the described variables. Table 3 describes the relationship between these variables.

The data for each variable in Table 2 generally describes the characteristics of the sample bank, while Table 3 presents the relationship between variables.

Table-3. Covariance matrix.

\begin{tabular}{|c|c|c|c|c|c|c|c|c|c|c|c|}
\hline & BUF & ROE & VOL & NPL & SIZE & LIQUID & SUBORD & PEER & LOANG & GDPG & SUPERV \\
\hline$\overline{B U F}$ & 1.00 & & & & & & & & & & \\
\hline ROE & $-0.14^{*}$ & 1.00 & & & & & & & & & \\
\hline VOL & $-0.16^{*}$ & $0.46^{*}$ & 1.00 & & & & & & & & \\
\hline NPL & $-0.28^{*}$ & 0.06 & 0.03 & 1.00 & & & & & & & \\
\hline SIZE & $0.20^{*}$ & -0.02 & $-0.11 *$ & 0.04 & 1.00 & & & & & & \\
\hline LIQUID & $0.16^{*}$ & -0.06 & -0.04 & $-0.13^{*}$ & $-0.09^{*}$ & 1.00 & & & & & \\
\hline SUBORD & $-0.18^{*}$ & 0.02 & 0.01 & $0.86^{*}$ & -0.01 & $-0.14^{*}$ & 1.00 & & & & \\
\hline PEER & $0.80^{*}$ & $-0.09^{*}$ & $-0.14^{*}$ & -0.06 & $0.23^{*}$ & $0.18^{*}$ & -0.06 & 1.00 & & & \\
\hline LOANG & 0.05 & $-0.20^{*}$ & -0.06 & $-0.14^{*}$ & $-0.23^{*}$ & $0.08^{*}$ & $-0.10^{*}$ & -0.02 & 1.00 & & \\
\hline GDPG & $-0.15^{*}$ & $0.12^{*}$ & $0.23^{*}$ & $0.31^{*}$ & $-0.27^{*}$ & $-0.16^{*}$ & $0.30^{*}$ & $-0.19^{*}$ & 0.00 & 1.00 & \\
\hline SUPERV & $0.18^{*}$ & 0.00 & $-0.09^{*}$ & 0.03 & $0.97 *$ & $-0.09^{*}$ & -0.02 & $0.23^{*}$ & $-0.22 *$ & $-0.25 *$ & 1.00 \\
\hline
\end{tabular}

Note: * represents statistically significant at least at the $10 \%$ level.

As can be seen from Table 3, in addition to the increase in bank loans, other indicators of bank operations have a significant correlation with the capital buffer, in which the correlation coefficient of peer pressure is as high as 0.80 .

The panel data used in this study is between the typical macroscopic panel data and microscopic data. It is dynamically unbalanced and contains a large amount of temporary information. In the study, the Fisher-type statistical method was first used to test the unit of non-stationary data. Root solves the asymptotic nature of the data and avoids surface regression in non-integrated non-stationary variables.

We calculate the regression by the moment estimation (GMM) method. The robustness is verified by a two-step delimitation procedure, which compares the estimated results of the system GMM with the known characteristic estimates.

The first delimitation procedure estimate (module I in Table 4) was conducted by POLS (pooled ordinary least squares), where the dependent variable and the explanatory variable are defined hierarchically. Since the pre-determined variable (the lagging dependent variable) is endogenous to the omitted fixed influence value, and violates the necessary condition of OLS consistency, the estimated value is a positive bias, and this value determines the high limit of the correlation coefficient.

The second defined procedure estimate (Module II in Table 4) resolves endogenous issues by removing fixed effects through LSDV. Since the relationship between the lag variable and the erroneous term is ignored, the variation within the group is biased, and the estimated coefficient of the predetermined variable becomes tilted downwards, thus defining a low limit. Although the sample of time units in the study is already greater than 30, as the time dimension of the panel increases, the estimated bias is still declining. In the study, instrumental variables (IVs) were used to solve this problem. There are many effective tools in the existing literature. The systematic GMM is used in this research. The regression system of difference and the regression of the levels combine to greatly enhance the statistical efficiency of the estimate. Modules III and IV in Table 4 were completed by the system GMM.

In order to remove the unique effects that are not observed, we use orthogonal deviations rather than first-order differences because the conversion of the first-order differences may increase the gap of the unstable panel data. We also use a two-step process that is more effective than one-step estimates. We may use two corrective measures because of possible minor standard errors that are inconsistent. First, we modified the variability and covariance matrix for finite samples. Second, we use the dynamic panel data down test program to determine the optimal number of tools.

Since the number of time items of data is more than the number of individuals in the panel, ie, $\mathrm{n}<\mathrm{T}$, the generalized moment estimator (GMM) is not applicable (the estimation method of GMM is a consistent estimator, ie there is no bias in the estimation when $n \rightarrow \infty$, but bias in Large deviations in the long panel). This study included bias-corrected least squares dummy variable (LSDVC). The estimated results are shown in Table 4 . 
Table-4. Panel tool variable valuation results.

\begin{tabular}{|c|c|c|c|c|c|}
\hline & I & II & III & IV & $\mathrm{V}$ \\
\hline \multirow[t]{2}{*}{$B U F_{t-1}$} & $0.655^{* * * *}$ & $0.586^{* * *}$ & $0.526 * * *$ & $0.641 * * *$ & $0.607 * * *$ \\
\hline & $(13.42)$ & $(5.64)$ & $(14.98)$ & $(27.92)$ & $(23.90)$ \\
\hline \multirow[t]{2}{*}{$R O E_{t}$} & $0.016^{* * * *}$ & $0.013^{*} *$ & $0.011 * * *$ & $0.010^{* * * *}$ & $0.014 * * *$ \\
\hline & $(3.89)$ & $(2.64)$ & $(2.92)$ & $(2.82)$ & $(2.92)$ \\
\hline \multirow[t]{2}{*}{$V O L_{t}$} & $-0.003 * * *$ & $-0.002 * *$ & $-0.002 *$ & -0.001 & $-0.002 * * *$ \\
\hline & $(-2.70)$ & $(-2.21)$ & $(-1.91)$ & $(-1.55)$ & $(-3.06)$ \\
\hline \multirow[t]{2}{*}{$N P L_{t}$} & $-0.120 * * *$ & $-0.109^{*}$ & $-0.154 * * *$ & $-0.112 * * *$ & $-0.101 * * *$ \\
\hline & $(-2.93)$ & $(-1.96)$ & $(-4.61)$ & $(-4.29)$ & $(-2.76)$ \\
\hline \multirow[t]{2}{*}{$S I Z E_{t}$} & $0.505^{* * * *}$ & 0.159 & $0.634 * * *$ & $0.389^{* *}$ & -0.054 \\
\hline & $(3.11)$ & (0.66) & $(3.31)$ & $(2.07)$ & $(-0.14)$ \\
\hline \multirow{2}{*}{ LIQUID $_{t}$} & $0.008 * *$ & 0.004 & 0.004 & 0.005 & 0.004 \\
\hline & $(2.37)$ & $(0.64)$ & $(0.96)$ & $(1.61)$ & $(0.73)$ \\
\hline \multirow{2}{*}{$S U P E R V_{t-1}$} & $-0.000^{*} * *$ & -0.000 & $-0.000^{*} * *$ & -0.000 & -0.000 \\
\hline & $(-3.09)$ & $(-0.94)$ & $(-4.03)$ & $(-1.52)$ & $(-0.39)$ \\
\hline \multirow[t]{2}{*}{$S U B O R D_{t}$} & 0.033 & 0.023 & 0.033 & 0.033 & 0.017 \\
\hline & $(0.69)$ & $(0.40)$ & $(0.74)$ & $(0.92)$ & $(0.36)$ \\
\hline \multirow[t]{2}{*}{$P_{E E R_{t}}$} & 0.392*** & $0.487^{*} * *$ & $0.591 * * *$ & $0.366^{* * * *}$ & $0.476^{* * * *}$ \\
\hline & $(4.20)$ & $(2.39)$ & $(11.88)$ & $(11.90)$ & $(16.22)$ \\
\hline \multirow[t]{2}{*}{$L O A N G_{t}$} & $-0.044 * * *$ & $-0.039 * *$ & $-0.031 * * *$ & $-0.023 * * *$ & $-0.036 * * *$ \\
\hline & $(-4.07)$ & $(-2.61)$ & $(-3.66)$ & $(-3.36)$ & $(-4.16)$ \\
\hline \multirow[t]{2}{*}{$G D P G_{t}$} & 0.093**** & $0.084 * *$ & $0.079^{* * *}$ & $0.071^{* * *}$ & $0.103^{* * *}$ \\
\hline & $(3.36)$ & $(2.69)$ & $(5.10)$ & $(5.19)$ & $(3.89)$ \\
\hline \multirow[t]{2}{*}{ Bankdept } & & & & 0.005 & \\
\hline & & & & $(0.11)$ & \\
\hline \multirow[t]{2}{*}{ TIME } & & & & & 0.007 \\
\hline & & & & & $(0.87)$ \\
\hline \multirow[t]{2}{*}{ Constant } & $-1.195 * * *$ & $-1.004 * *$ & 0.000 & 0.317 & \\
\hline & $(-3.22)$ & $(-2.27)$ & (.) & $(0.14)$ & \\
\hline$R^{2}$ & 0.893 & 0.845 & & & \\
\hline AR1 & & & 0.533 & 0.980 & \\
\hline AR2 & & & 0.807 & 0.292 & \\
\hline Hansen & & & 1.000 & 1.000 & \\
\hline
\end{tabular}

Note: The dependent variable is the bank's capital buffer and is calculated on the basis that the natural number of capital exceeds the prescribed minimum value. In addition to lagged dependent variables, explanatory variables include companyspecific and macroeconomic factors. The first column of data is estimated by mixing the OLS, and the second column is the fixed effect of the panel model estimated by the bias correction estimate (LSDV). The third and fourth columns are estimated by the system GMM (Sys.GMM). Endogenous variables are set to lag one to five. In all models (I to V), the quarterly and annual variables are included, but their correlation coefficients are omitted. *, ***, and *** indicate significant levels at the levels of 0.1 , 0.05 , and 0.01 , respectively. The $Z$ value (first column) and the $t$ value (second to fifth column) are indicated in parentheses. The Hansen test refers to tests that over-recognize restrictions, and tests $\operatorname{AR}(1)$ and $\operatorname{AR}(2)$ refer to first-order and second-order autocorrelations. The p-values are reported for these tests.

\section{Analysis of Results}

The GMM estimation results reflected in Table 4 are robust to the demarcation process. As expected, module I, estimated by POLS, reflects the highest correlation coefficient estimate (positive bias) on the lagged dependent variable; fixed effect module, module II, has the lowest estimate (negative bias); module III And IV, based on GMM tools, intermediate values. The correlation coefficient estimates and significance levels of the remaining explanatory variables remained largely similar. In addition, the automatic correlation test of the tool module shows that the second-order series of relevant default conditions are met, and the Hansen test does not reflect the over-determined limitations on the estimation equation. The consistency of the two tests can be seen in module $\mathrm{V}$ of Table 4 .

\subsection{The Effect of Capital Supervision on the Operation of Commercial Banks}

The correlation coefficient estimated by the lagged dependent variable BUFt-1 is significant at the 0.01 level in all models and is positive, with a maximum of 0.655 , indicating that the variable is continuous, and the adjustment rate of the capital buffer is slow, within the range of values $(0<\theta<1)$. The rate of adjustment of the 
capital buffer is close to that of the capital buffers in the United Kingdom and Hong Kong (see Francis and Osborne (2009)). The results of the study support the existing theory of capital buffering, ie, capital adjustment costs affect bank decisions.

The correlation coefficient of the ROE variable is positive in all modules and is significant, indicating that some of the bank's earnings have been converted into capital, proving that PSC financing theory. At the same time, this also reflects the highly centralized ownership of the banking industry and the limited external funding sources of commercial banks.

In all models, the correlation coefficient of the variable VOL is negative. Except for no significant significance in Model IV, it has significant significance in other models, and it has significant significance in Model III at the level of 0.1, which indicates that Bank of China is profitable. Stable and high level of capital ratios. Similarly, non-performing loans, NPL, are part of the bank's risk portfolio and are negatively correlated with the capital buffer. They are significant at the level of 0.1 in Module II. This indicates that banks with lower capital buffers have higher non-performing loan ratios and capital. The non-performing loans of banks with higher buffering ratios are low, which fully shows that capital supervision has a great influence on commercial banks.

Bank size, SIZE, is significant in Models I, III, and IV, positively correlated and highly correlated, but not significant in Models II and V, and the correlation coefficient is negative in Model V, indicating that The impact of capital regulation on the size of banks is diverse. Some banks are large in scale but their capital buffers are not high. Sometimes, the scale of a bank is not directly related to capital regulation, but it is directly related to the institutional nature of the bank. In general, the amount of capital retained by stateowned listed banks will be lower, while the amount of capital retained by joint-stock listed banks will be higher. Similarly, the variable LIQUID is significant only at the 0.01 level in Model I, indicating that banks with larger liquid assets do not necessarily have large capital buffers, and capital regulation has different effects on commercial banks of different natures.

\subsection{Impact of Regulatory Pressure and Market Pressure on Capital Operation of Commercial Banks}

The variable supervisory pressure SUPERVt-1 is endogenous, both 0.000 and negative. It has significant significance in tool models I and III, indicating that the rating result will often affect the positive adjustment of the bank's follow-on capital ratio, and the bank will increase the capital ratio. Or reduce risk exposure to respond to avoid increased monitoring.

The correlation coefficient for variable subprime debt SUBORD is positive but not significant, indicating that the interbank market does not appear to be binding on the bank's capital ratio, and uninsured loan holders may not play a significant role in restricting banks. This is consistent with the recent findings of Mendonc and Loures (2009) who did not find empirical evidence of market constraints. One of the reasons may be the underdeveloped financial system.

On the contrary, the impact of inter-bank competition on commercial bank net capital retention is obvious. As expected, the variable PEER is positive and significant. Overall, market constraints arise from competitors rather than debt holders, and Alfon, Argimon, and Bascunana-ambrós (2004) also obtained the same results. However, pressure from peers on financial stability may also have a negative impact, leading banks to lower their capital ratios.

\subsection{Impact of Economic Environment on Commercial Banks' Net Capital Retention}

Both the capital buffer and the loan growth and the economic growth have a reaction. In all models, the loan growth coefficient is negative and significant. The economic growth coefficient is positive and significant. The loan increases the net capital and the economic growth net capital also increases. The increase indicates that there is a counter-cyclical relationship between the capital buffer and the economic cycle. That is to say, if the economy is in an upward trend, banks will increase the capital buffer. This result is inconsistent with the previous research results (Alfon et al., 2004). This shows that China's macroprudential regulation has already played a role. After experiencing losses, the real economy has declined, but the banking system will remain relatively stable.

\section{Conclusion and Suggestion}

This paper empirically analyses the impact of macroprudential supervision on capital operation of commercial banks using the dynamic unbalanced panel system GMM model, and finds that the capital buffer plays an active role in supervising the commercial banks in China. 1) With the strengthening of macroprudential supervision, the bank's non-performing loan ratio is declining, the bank's profits are gradually increasing, and profits are transformed into the source of capital, forming a virtuous circle. However, there is no direct link between the size of the bank and capital regulation. 2) The bank rating results will affect the active adjustment of the bank's follow-on capital ratio, and banks will avoid increasing the monitoring by increasing the capital ratio. Similarly, peer competition has a significant impact on commercial bank capital operations, but subprime mortgage debt does not. As the financial system is underdeveloped, market constraints have not played their due role. 3) The banking system is sound. When the economy goes up, banks 
will increase their net capital and increase their capital buffers, forming a counter-cyclical relationship with the economic cycle, and they will play a role of macro-prudential supervision.

Based on the above findings, we have come to the following policy recommendations: 1) Capital supervision plays a very good role in supervising China's commercial banks, guiding China's commercial banks to establish a capital constraint mechanism, and improving the bank's internal capital supplement mechanism. At the same time, we must appropriately improve the banking ownership structure and increase the sources of external funds for commercial banks. 2) Bank rating results and peer competition have a great influence on the capital operation of commercial banks in China. However, due to the lack of transparency in the financial system, the inter-bank market cannot constrain the capital ratio of banks. To this end, we must increase the transparency of the financial system so that uninsured loan holders can play a significant role in binding banks. 3) Commercial banks basically meet the requirements for prudent management of counter-cyclical capital. On this basis, banking supervision departments must strengthen supervision and make bank capital buffers appear more counter-cyclical.

\section{References}

Alfon, I., Argimon, I., \& Bascũnana-ambrós, P. (2004). What determines how much capital is held by UK banks and building societies? FSA Occasional Paper No. 22. FSA, London.

Ayuso, J., Pérez, D., \& Saurina, J. (2004). Are capital buffers pro-cyclical? Evidence from Spanish panel data. Journal of Financial Intermediation, 13(2), 249-264.

Blum, J. (2002). Subordinated debt, market discipline, and banks' risk taking. Journal of Banking and Finance, 26(7), 14271441 .

Estrella, A. (2004). The cyclical behaviour of optimal bank capital. Journal of Banking and Finance, 28(6), 1469-1498.

Fonseca, A. R., \& González, F. (2010). How bank capital buffers vary across countries: The influence of cost of deposits, market power and bank regulation. Journal of Banking and Finance, 34(4), 892-902.

Francis, W., \& Osborne, M. (2009). On the behaviour and determinants of risk-based capital ratios: Revisiting the evidence from UK banking institutions. In: FSA Occasional Paper, 31. FSA, London.

Jokipii, T., \& Milne, A. (2008). The cyclical behaviour of European bank capital buffers. Journal of Banking Finance, 32(8), $1440-1451$

Mendonc, A. H., \& Loures, R. (2009). Market discipline in the Brazilian banking industry: An analysis for the subordinated debt holders. Journal of Regular Economics, 36(3), 286-307.

Milne, A., \& Whalley, A. E. (2001). Bank capital regulation and incentives for risk-taking. Cass Business School Research Paper.

Milnes, A. (2004). The inventory perspective on bank capital. Cass Business School Research Paper.

Nier, E., \& Baumann, U. (2006). Market discipline, disclosure and moral hazard in banking. Journal of Financial Intermediation, 15(3), 332-361. 